\title{
Adaptive Re-Use Principles in Historic Hotel Buildings in Melaka And George Town
}

\author{
Lilawati Ab Wahab",a , Noor Aishah Mohd.Hamdan², Nor Suzila Lop ${ }^{3}$ and Izatul Faritta Mohd Kamar ${ }^{4}$ \\ 1,2,3,4 Department of Quantity Surveying, Faculty of Architecture, Planning and Surveying, Universiti Teknologi MARA Seri Iskandar Campus, \\ Seri Iskandar, 32610 Perak, Malaysia.
}

\begin{abstract}
Adaptive re-use of historic buildings is a process of changing the original function of the historic buildings to another function that can optimise the use of existing historic buildings. The selection of appropriate new function is an important factor in determining the success of adaptive re-use of historic buildings. However, adaptive re-use work done on historic buildings on the World Heritage Site is not an easy task due to rules and principles outlined by local and international charters that must be abide by. This research is conducted to gather the true picture of applied adaptive re-use principles that has been done on heritage hotels available in Melaka and George Town World Heritage Sites. This research is started with an inventory that led to the discovery of 35 hotels which applied the principle of adaptive re-use of historic buildings. Based on this finding, 4 historic hotels from adaptive re-use applications have been selected as the case studies. Results of the case studies carried out show that the level of conservation of heritage hotel is moderate and measures of control should be taken to ensure the privileges of heritage hotel. As a result of this research, a number of suggestions are made to ensure that adaptive re-use work done in the future will be conducted as optimum as possible according to the adaptive re-use and conservation principles.
\end{abstract}

\section{Introduction}

Adaptive re-use is broadly defined as any building work and intervention to change its capacity, function or performance to adjust, reuse or upgrade a building to suit new conditions or requirements (Douglas, 2006). Adaptive re-use is a wise move to ensure that a building restored, given new impetus and should be used with. Orbasli (2008) stated that adaptive re-use works is a process in which the building has been modified for the new use and so leave the usage of time.

Adaptive re-use work involve works such as conservation, modification, repair, maintenance and consolidation (Australia ICOMOS, 2002). Bullen (2007) stated that although there are many qualifying factors, the concept of adaptive re-use has significantly support a positive strategy to make the built environmnet more sustainable.

\section{Adaptive Re-Use of Historic Buildings}

Adaptive re-use of historic building is one of the best methods that can help a historic building keeps well conserved (Ahmad and Badarulzaman, 2003). Adaptive re-use work involve works such as conservation, modification, repair, maintenance and consolidation (Australia ICOMOS, 2002). Bullen and Love (2011)

\footnotetext{
a Corresponding author: lilawati@perak.uitm.edu.my
}

stated that the change of use may require refurbishment and/or complete renovation of existing buildings or structures. It's part of the rules that have the effect of protecting historical buildings from collapsing (Ashurst, 2006). According to Ashworth and Larkham (1994) when a historic building collapsed, the history that was recorded in the same building also died and disappeared without being remembered by future generations.

Adaptive re-use works on a historic building that has been listed as a National Heritage Building should be done in accordance with the principles of conservation which have been set out in the National Heritage Act 2005 and also conservation guidelines provided by the local authorities of the city in which it is located. In addition to the acts and national guidelines, the owner of historic buildings also have to comply with international charters in conduct of adaptive re-use of historic buildings (Department of National Heritage, 2007).

Adaptive re-use of historic building as a hotel in the UNESCO World Heritage Site of Melaka and George Town are not only able to make historic buildings prevail, but it also has a greater impact, extensive and profound. These buildings may also become important assets to develop a local tourism industry (Pedersen, 2002). Orbasli (2000) concurred that the tourism sector is a significant contributor to the economy of the city or the historical center. Adaptive re-use of historic buildings to a hotel will meet the needs of the tourism sector which 
can provide a good return to the hotel, shops, businesses and positively support the country's tourism sector.

\section{Objectives of Research}

The main objectives of this research are:

i. To identify the common buildings element that had been renovated and maintained in adaptive re-use of historic building as a hotel in UNESCO World Heritage Site of Melaka and George Town.

ii. To assess the adaptive re-use of historic building practice level as a hotel based on the principles of conservation in the UNESCO World Heritage Site of Melaka and George Town.

iii. To propose basic guidelines for assessing the level of adaptive re-use of historic building as a hotel based on the principle of conservation of UNESCO World Heritage Site.

\section{Research Methodology}

For this research, qualitative methods was used in the study. The inventory has been carried out around Melaka and George Town World Heritage Site and as a result have led to the discovery of 35 hotels with application of adaptive re-use principles. 7 hotels are located in Melaka and 28 hotels located in George Town. The hotels have been screened to identify the four historic hotels that suitable as a case study for this research based on several criteria to represent another 31 hotels. These criteria are:

i. The application of the adaptive reuse principles and the historic buildings located within the conservation zone of world heritage sites.

ii. Heritage Hotel.

iii. The legacy that has interesting historical background.

iv. The heritage design which has interesting architecture value.

For this research, four ideal hotels were identified as samples for case studies:

i. Hotel Puri in Melaka World Heritage Site.

ii. Heeren House in Melaka World Heritage Site.

iii. Cheong Fatt Tze Mansion in George Town World Heritage Site.

iv. Hutton Lodge in George Town World Heritage Site. Two approaches have been used throughout this case study:

i.Observation - observation of architectural elements based on the application of the adaptive re-use and conservation principles in heritage hotels

ii. Interviews - Interview with hotel owners and employees to identify the application level of adaptive reuse and conservation principles used.

\section{Analysis of Case Study}

Analysis of adaptive re-use work and conservation done for four case studies are as follow.
Table 1: Case study 1 - Hotel Puri at Banda Hilir, Melaka

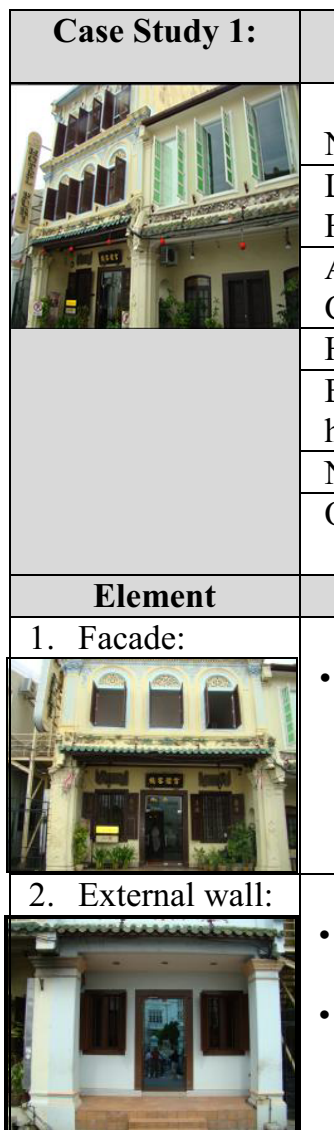

- The hotel retains its original external walls

- The walls were badly damaged and cannot be repaired, a new wall was built according to the specifications of the original wall. While on the damaged wall, the repair works were done carefully, especially on the plastering of the walls.

- Internal wall or wall divider is the largest element modified in Hotel Puri.

- New partition wall constructed according to new floor plan to create guest rooms. A dividing wall was built in every room to create a toilet and a bathroom in the room for the convenience of hotel guests.

- Many adjustments had to be made to internal wall to meet the new function as a hotel.

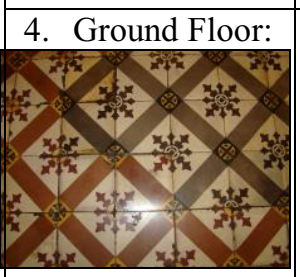

- The existing cement floor was maintained and repair works done on the damaged floor which patch the potholes and cracks.

5. Upper Floor:

- A lot of damage has occurred on the upper floor as timber was used for the element. Conservation work has been 


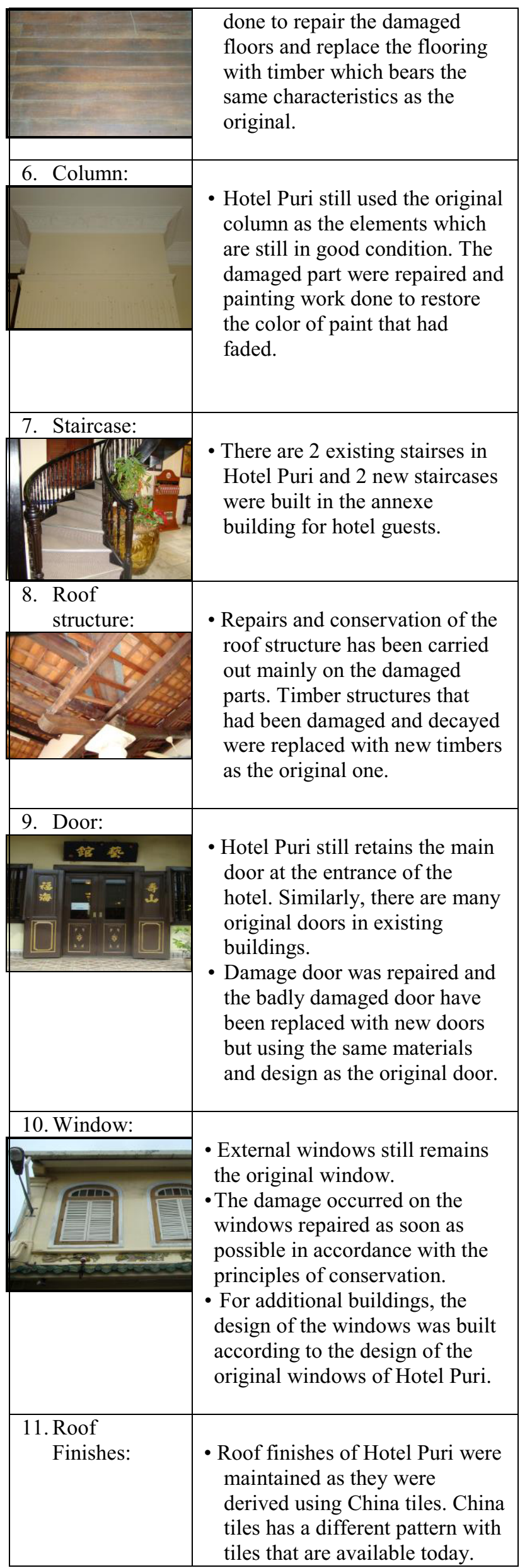

\begin{tabular}{|c|c|}
\hline 201 & $\begin{array}{l}\text { - China tiles that has been broken } \\
\text { and damaged, were replaced } \\
\text { with China tiles purchased from } \\
\text { nearest building owners which } \\
\text { no longer use Genting China on } \\
\text { their own building. }\end{array}$ \\
\hline $\begin{array}{l}\text { 12. Ceiling } \\
\text { Finishes: }\end{array}$ & $\begin{array}{l}\text { - The top floor still retains its old } \\
\text { ceiling finishes. Repair works } \\
\text { were only carried out on the } \\
\text { damaged and peel par. } \\
\text { - A new type of plaster finish } \\
\text { ceiling fans have been installed } \\
\text { in the hotel lobby to provide } \\
\text { more attractive finish to the } \\
\text { ceiling finishes of the hotel. }\end{array}$ \\
\hline 13. Wall Finishes: & $\begin{array}{l}\text { - Hotel Puri maintains the } \\
\text { existing wall finishes, } \\
\text { especially in the hotel lobby. } \\
\text { - Most of the existing wall } \\
\text { finishes at the hotel was } \\
\text { damaged and uprooted. } \\
\text { - Repairing works have been } \\
\text { done to the wall finishes to } \\
\text { follow the originals. }\end{array}$ \\
\hline 14. & $\begin{array}{l}\text { - Floor finishes at Hotel Puri are } \\
\text { also almost entirely broken and } \\
\text { uprooted. The floor finish has } \\
\text { been replaced by a similar } \\
\text { packaging with original tile } \\
\text { specially imported from } \\
\text { England. }\end{array}$ \\
\hline $\begin{array}{l}\text { 15. Building } \\
\text { facilities: }\end{array}$ & $\begin{array}{l}\text { - To ensure Hotel Puri provides } \\
\text { maximum comfort and security } \\
\text { to its guests, building facilities } \\
\text { such as air conditioning } \\
\text { systems and fire fighting } \\
\text { system have been installed } \\
\text { throughout the building. } \\
\text { Although these building } \\
\text { facilities crippled authenticity } \\
\text { of Hotel Puri, building services } \\
\text { is an important element that } \\
\text { needs to be in a hotel. }\end{array}$ \\
\hline $\begin{array}{l}\text { 16. Architectural } \\
\text { decoration: }\end{array}$ & $\begin{array}{l}\text { - No additional architectural } \\
\text { decoration done to the existing } \\
\text { ones because they are quite } \\
\text { interesting and has a value of its } \\
\text { own. } \\
\text { - There are many architectural } \\
\text { jewels plastered, remain on the } \\
\text { external walls of Hotel Puri. } \\
\text { These decorations have a }\end{array}$ \\
\hline
\end{tabular}




\begin{tabular}{|l|l|}
\hline & $\begin{array}{l}\text { natural backdrop, like the } \\
\text { decoration of plants and } \\
\text { animals that are hard to find in } \\
\text { other buildings. }\end{array}$ \\
\hline
\end{tabular}

Table 2: Case study 2 - Heeren House at Banda Hilir, Melaka

\begin{tabular}{|l|l|}
\hline Case Study 2: & \multicolumn{1}{c|}{ Detail } \\
\hline & $\begin{array}{l}\text { Name: Heeren House, Melaka. } \\
\text { Heritage Site, Melaka. }\end{array}$ \\
\hline & $\begin{array}{l}\text { Address: No.1, Jalan Tun Tan } \\
\text { Cheng Lock, 75200 Melaka. }\end{array}$ \\
\hline Hotel type: Guest House.
\end{tabular}

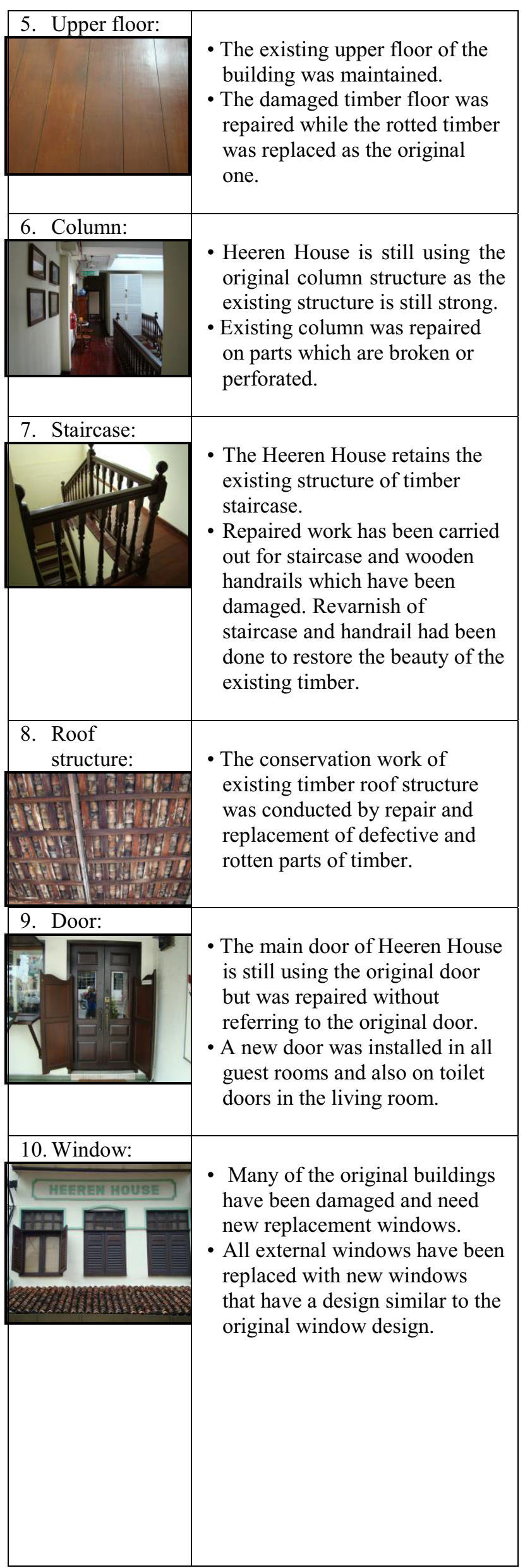




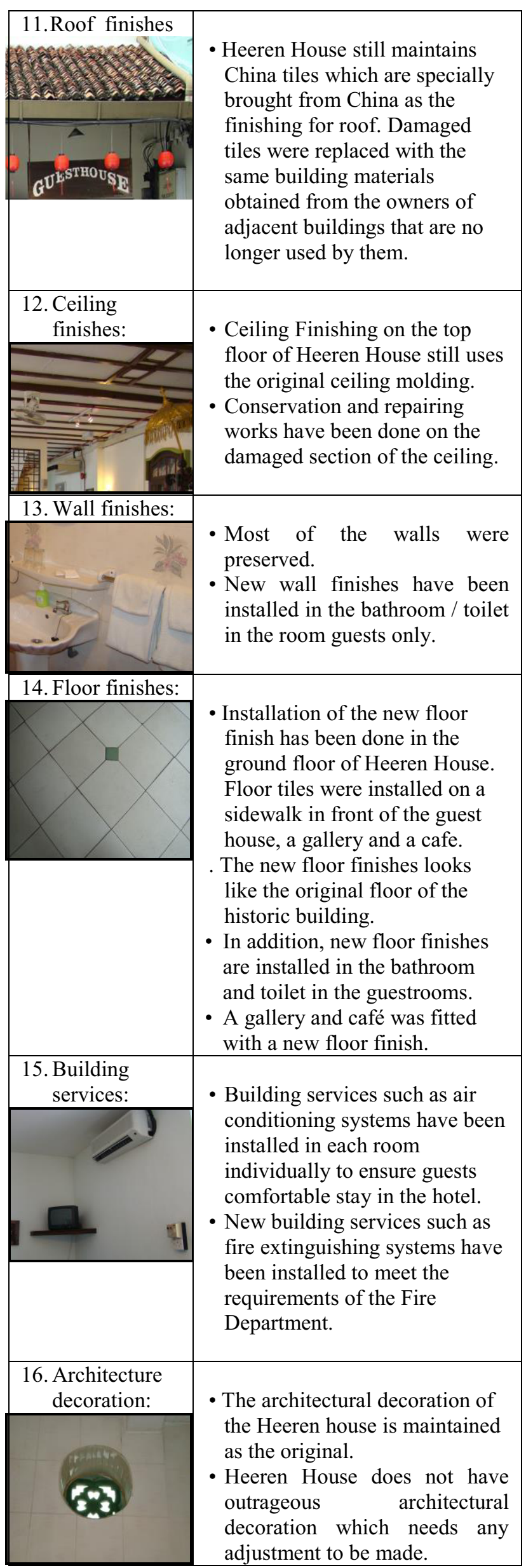

Table 3: Case Study 3 - Cheong Fatt Tze Mansion at George Town, Pulau Pinang

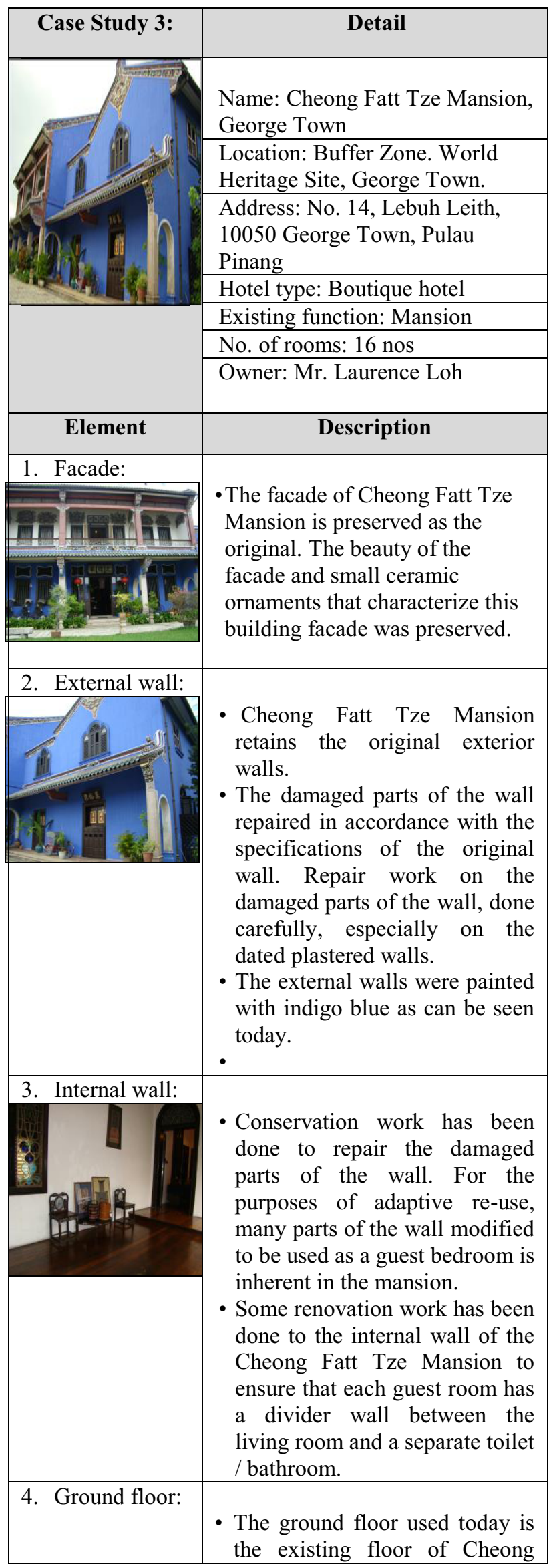




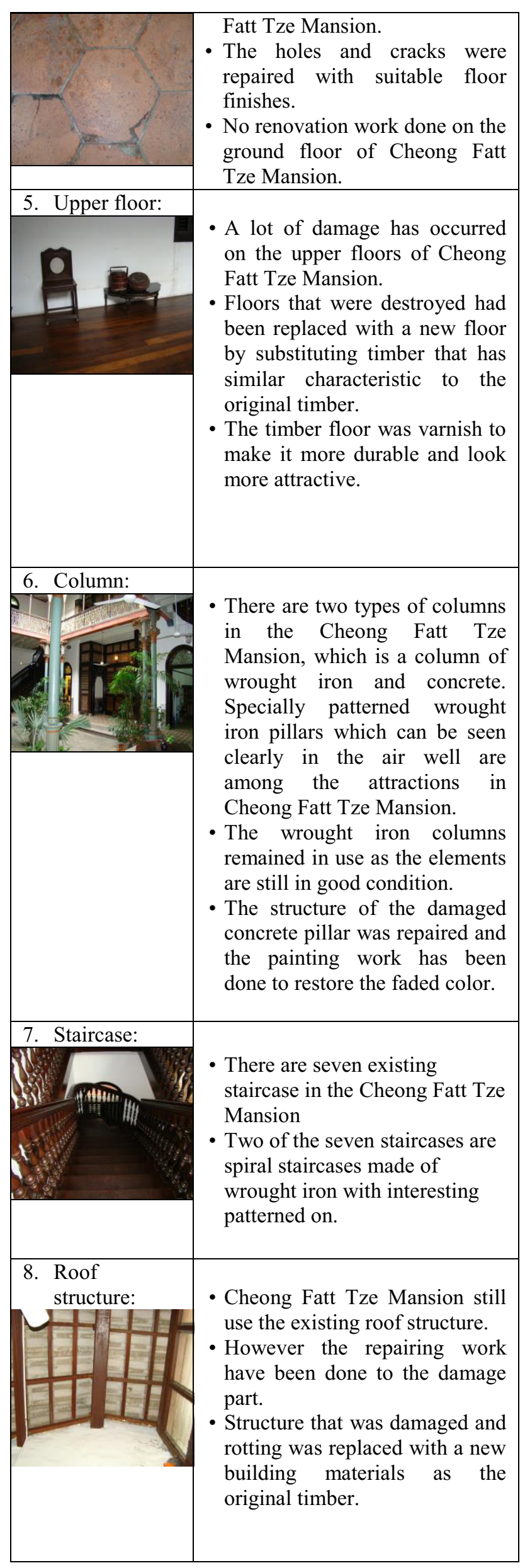

\begin{tabular}{|l|l|} 
- Cheong Fatt Tze Mansion still \\
preserves the original main \\
door at the entrance of the hotel \\
similar to the other doors in the \\
mansion. \\
- At one time this old mansion \\
was abandoned and not \\
maintained, then many doors \\
that have been damaged. \\
- The door, which suffered severe \\
damages have been repaired \\
and repainted as the original \\
door.
\end{tabular}




\begin{tabular}{|c|c|}
\hline & more attractive. \\
\hline 13. Wall finish & $\begin{array}{l}\text { - Cheong Fatt Tze Mansion used } \\
\text { 'fresco' formed from lime } \\
\text { plaster in many parts of the } \\
\text { living room. } \\
\text { - Most of it was damaged but } \\
\text { conservation work done by } \\
\text { using the grouting injection } \\
\text { technique. } \\
\text { - The fresco repainted and } \\
\text { 'fresco' line was repainted in } \\
\text { black Chinese ink mixed with } \\
\text { glue }\end{array}$ \\
\hline 14. Flo & $\begin{array}{l}\text { - There are three types of floor } \\
\text { finishes used in Cheong Fatt } \\
\text { Tze Mansion. } \\
\text { - First, the floor tiles with } \\
\text { geometric patterned which have } \\
\text { been used in most of the space } \\
\text { inside the mansion. } \\
\text { - Second, the terracotta floor } \\
\text { finishes which have been used } \\
\text { in most of the bedrooms. } \\
\text { - The third floor finishes is a } \\
\text { piece of granite that was used } \\
\text { on the pavement and air wells. } \\
\text { - Floor finishes at Cheong Fatt } \\
\text { Tze Mansion also been severely } \\
\text { damaged. The floor of the } \\
\text { storage containers were washed } \\
\text { and replaced with floor finishes } \\
\text { as the original and specially } \\
\text { imported from China. As for } \\
\text { the broken granite slabs, they } \\
\text { have been replaced with granite } \\
\text { collected from nearby shop that } \\
\text { no longer use in the building. }\end{array}$ \\
\hline $\begin{array}{r}\text { 15. Building } \\
\text { services: }\end{array}$ & $\begin{array}{l}\text { - Cheong Fatt Tze Mansion was } \\
\text { built hundreds years ago. No } \\
\text { building services installed in } \\
\text { the mansion at the time. Most } \\
\text { of the existing building services } \\
\text { are installed today after the } \\
\text { owners decided to adaptive re- } \\
\text { use of Cheong Fatt Tze } \\
\text { Mansion as a hotel. } \\
\text { - Building services such as air } \\
\text { conditioning have been } \\
\text { installed to ensure hotel guests } \\
\text { receive optimum comfort } \\
\text { during the stay. Air } \\
\text { conditioning has been installed } \\
\text { in many parts of the Cheong } \\
\text { Fatt Tze Mansion. }\end{array}$ \\
\hline $\begin{array}{l}\text { 16. Architecture } \\
\text { Decoration: }\end{array}$ & $\begin{array}{l}\text { - Architectural decoration at the } \\
\text { outer wall of Cheong Fatt Tze }\end{array}$ \\
\hline
\end{tabular}

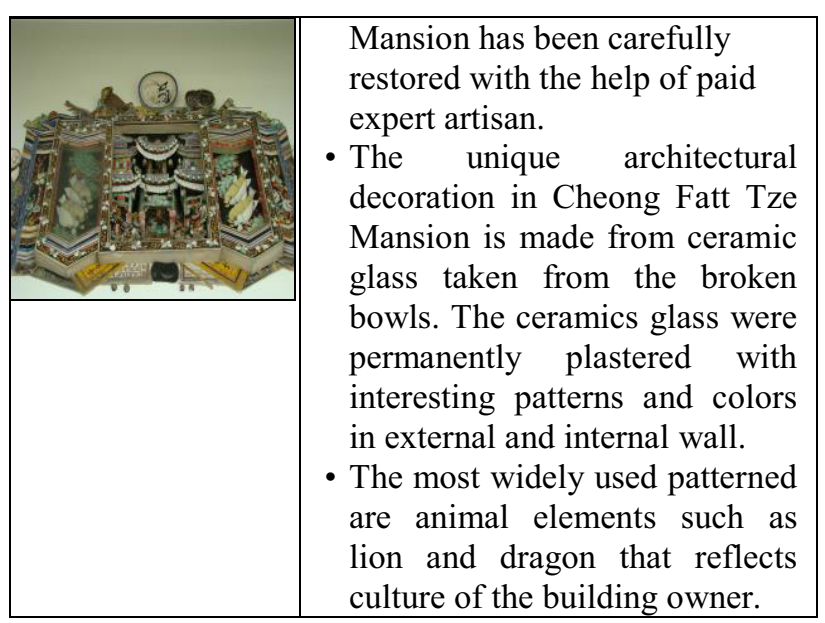

Table 4: Case Study 4 - Hutton Lodge at George Town, Pulau Pinang

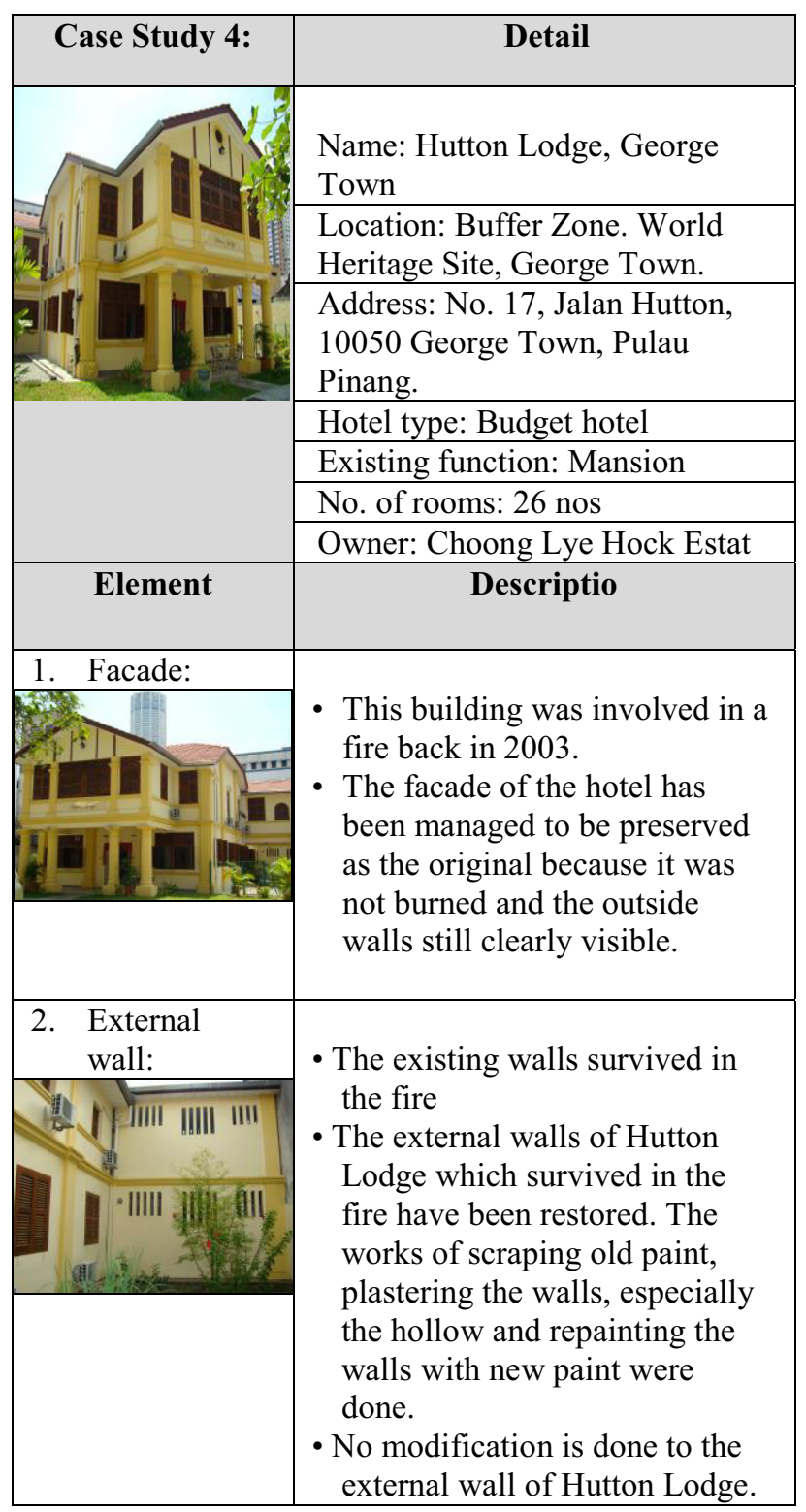




\begin{tabular}{|c|c|}
\hline 3. Internal wall: & $\begin{array}{l}\text { - The internal walls which } \\
\text { survived in the fire have been } \\
\text { restored while the } \\
\text { reconstruction is done for the } \\
\text { wall which was destroyed by } \\
\text { fire. } \\
\text { - Several additions have been } \\
\text { made to the wall to ensure } \\
\text { Hutton Lodge can meet new } \\
\text { function as a hotel. } \\
\text { - The existing walls have been } \\
\text { modified according to the new } \\
\text { floor plan to change the } \\
\text { function of from bungalow to a } \\
\text { hotel. }\end{array}$ \\
\hline 4. Gro & $\begin{array}{l}\text { - The ground floor which } \\
\text { survived the fire has been } \\
\text { rebuilt to get stronger floor } \\
\text { structure. }\end{array}$ \\
\hline Uppe & $\begin{array}{l}\text { - The reconstruction was done on } \\
\text { the upper floor which } \\
\text { completely burnt the timber } \\
\text { floor when the fire broke out. } \\
\text { - Fire Department has banned the } \\
\text { reuse of timber floors due to } \\
\text { fire safety. } \\
\text { - A new concrete floor was built } \\
\text { to replace the timber floor. }\end{array}$ \\
\hline & $\begin{array}{l}\text { - The existing column is } \\
\text { conserved and conservation } \\
\text { work has been carried out on } \\
\text { the damaged part due to the } \\
\text { fire. } \\
\text { - No renovation work done to the } \\
\text { column of Hutton Lodge. }\end{array}$ \\
\hline 7. Staircase: & $\begin{array}{l}\text { - The existing staircase which } \\
\text { destroyed in the fire has been } \\
\text { replaced with a new staircase } \\
\text { using concrete and wooden } \\
\text { handrail. The staircase was built } \\
\text { in its original position. } \\
\text { - As for the annex building, a } \\
\text { new concrete stairses was built } \\
\text { for the convenience of hotel } \\
\text { guests staying in rear wing of } \\
\text { the hotel. }\end{array}$ \\
\hline $\begin{array}{ll}\text { 8. } & \text { Roof } \\
& \text { Structure: }\end{array}$ & $\begin{array}{l}\text { The new roof structure was } \\
\text { built using timber as the } \\
\text { original structure was destroyed } \\
\text { in the fire. }\end{array}$ \\
\hline
\end{tabular}

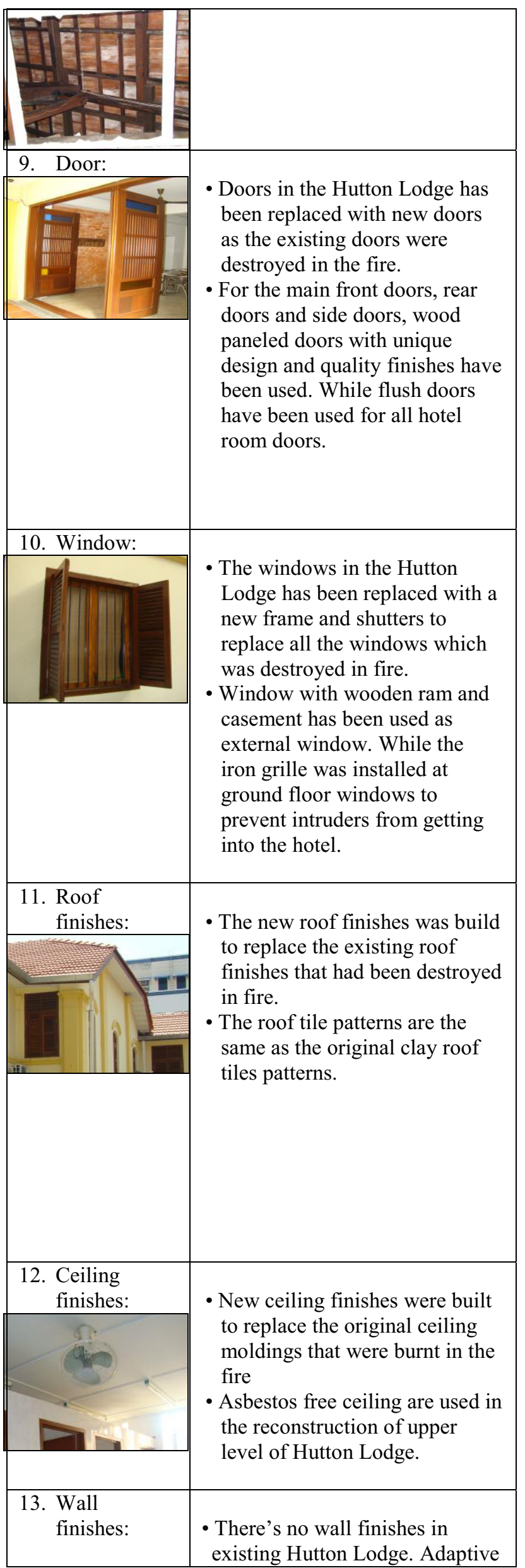




\begin{tabular}{|c|c|}
\hline & $\begin{array}{l}\text { re-use work to change bungalow } \\
\text { into a comfortable budget hotel } \\
\text { floors needs wall finishes. } \\
\text { - Wall tiles measure } 1 \text { 'x 1' used in } \\
\text { the toilet in each of the room and } \\
\text { also in the shared toilet used by } \\
\text { guests staying at dormitari. }\end{array}$ \\
\hline $\begin{array}{l}\text { 14. Floor } \\
\text { finishes: }\end{array}$ & $\begin{array}{l}\text { The new floor finishes was } \\
\text { installed in Hutton Lodge due } \\
\text { to the existing floor finish has } \\
\text { been destroyed by fire in the } \\
\text { past. } \\
\text { - Almost the entire ground floor } \\
\text { of the Hutton Lodge using } \\
\text { cement as floor finishes. } \\
\text { - However, in certain areas such } \\
\text { as on the front porch and the } \\
\text { porch edge Hutton Lodge has a } \\
\text { floor tile to form a pattern on } \\
\text { the floor. } \\
\text { - The carpet was installed in the } \\
\text { guest rooms for the comfort of } \\
\text { hotel guests. } \\
\text { - 1'x 1' sized floor tile has been } \\
\text { used in the toilet }\end{array}$ \\
\hline $\begin{array}{l}\text { 15. Building } \\
\text { services: }\end{array}$ & $\begin{array}{l}\text { - The original building of Hutton } \\
\text { Lodge does not have any } \\
\text { building services. } \\
\text { - Building services such as air- } \\
\text { conditioning systems, cctv } \\
\text { camera systems, fire protection, } \\
\text { internet and television services } \\
\text { have been installed for the } \\
\text { comfort and safety of the } \\
\text { guests. }\end{array}$ \\
\hline $\begin{array}{l}\text { 16. Architectural } \\
\text { decoration: }\end{array}$ & $\begin{array}{l}\text { Architectural decoration in the } \\
\text { Hutton Lodge is very simple } \\
\text { and has been retained as before. }\end{array}$ \\
\hline
\end{tabular}

\section{Findings}

The findings of this research will hopefully help people in gaining knowledge, understanding of data and information on adaptive re-use of historic building as a hotel and adaptive re-use principle that has been done based on the principles of conservation.

\subsection{First Research Findings}

The results of the study conducted found that most frequent element renovated building in the historic building as the hotel adaptive re-use frequency are the wall, a building, wall finishes, ceiling and floor finishes.
These five elements have of percentages modification exceeds $10 \%$ as compared to the other elements. Wall is an elements that has the highest percentages of modification in adaptive re-use work of historic building as a hotel. Frequent modification done is the addition of walls in order to form more areas for living rooms and toilets. Unfortunately, most of the walls are not built in accordance with the original building material as the original existing wall.

\subsection{Second Research Findings}

The results of the observations that have been made over 4 selected hotels have shown that only two from four hotels achieved adaptive re-use principles in accordance with the principles of conservation. As a result of this finding, it indicate that most hotel owners are not focused on conservation principles outlined by the local authorities in carrying out the adaptive re-use of historic building works as a hotel.

\subsection{Third Research Findings}

The proposed assessment method is not only suitable for adaptive re-use of historic building as a hotel but also can be used to evaluate the adaptive re-use of historical buildings with other functions. Simple formula introduced the number of architectural elements preserved which meets the principles of conservation will be divided by the total number of elements that are evaluated. Then multiply by one hundred to obtain the percentage level of adaptive re-use made by the historic buildings.

\section{References}

1. Ahmad, A. G. and Badarulzaman, N. Adaptive Re-Use for Sustainable Heritage Tourism in Malaysia. Journal of Tourism. 51(2). 205-214. (2003)

2. Ashurst, J. Conservation of Ruins. Oxford, Butterworth-Heinemann. (2006).

3. Ashworth, G.J. and Larkham, P.J. Building a New heritage: Tourism, Culture and Identity in the New Europe. London, Routledge. (1994)

4. Australia International Council on Monument and Site (ICOMOS). ICOMOS International Cultural Tourism Charter: Principles and Guidelines for Managing Tourism at Places of Cultural and Heritage Significance. Victoria: Australia International Council on Monument and Site (ICOMOS) Incorporated. Retrieved 02/06/2015,from

http://australia.icomos.org/publications/burracharter- practice- notes/. (2002)

5. Bullen, P. A.and love, P. E. D). Adaptive Reuse of Heritage Buildings. Structural Survey. 29(5).411-421. (2011)

6. Department of National Heritage. 50 Warisan Kebangsaan. Kuala Lumpur, Kementerian 
Perpaduan, Kebudayaan, Kesenian dan Warisan Malaysia. (2007)

7. Douglas, J. Building Adaptation, $2^{\text {nd }}$ ed., Heriot Watt University, Edinburg, United Kingdom, Butterworth-Heinemann. (2006)

8. Feildin B. M. Conservation of Historic Buildings, London, Butterworth Scientific. (1982)

9. Ismail, M.Y. Rehabilitation of Heritage Building in Malaysia. Undergraduate Dissertation, Shah Alam, Universiti Teknologi MARA.

10. Orbasli, A. Tourist in Historic Towns. London \& New York: E \& FN Spon.. (2000)

11. Orbasli, A. Architectural Conservation. Oxford, Blackwell Science Ltd. (2008)

12. Pedersen, A. Managing Tourism at World Heritage Sites: A Practical Manual for World Heritage Site Managers. UNESCO World Heritage Centre. (2002) 